\title{
RADIOACTIVE PHOSPHORUS IN STUDIES ON THE METABOLISM OF NORMAL AND NEOPLASTIC TISSUES
}

\author{
By A. MARSHAK \\ (From the Tuberculosis Control Division, U. S. Public Health Service, and College of Medicine, \\ New York University, New York City)
}

Since, in the past year, there have appeared one book and three reviews covering wholly or in part the subject matter indicated above $(1-3)$, this review will confine itself to those aspects which have not been fully presented or in which the interpretations differ from those of the present reviewer. The retention of $\mathrm{P}^{32}$ by various normal and neoplastic tissues has been well summarized as has phospholipid metabolism and will not therefore be considered here $(4,5)$.

\section{Phosphate esters and carbohydrate metabolism}

The rate of penetration of phosphate ion into muscle was shown to be relatively slow, so that the specific activity $\left(\mathrm{P}^{32} / \mathrm{P}^{31}\right)$ of the inorganic phosphate (IP) within the cell was for a long time much lower than that of the extracellular IP and was shown to be a function of temperature (6). Assuming that the extracellular space for phosphorus and sodium were the same, Hevesy and Rebbe estimated that IP is incorporated into organic phosphate at the rate of $21 \mu \mathrm{g} / \mathrm{gm}$ tissue/ day (7). Direct determination of extra- and intracellular radioactive inorganic phosphate $\left(\mathrm{P}^{*} \mathrm{O}_{4}\right)$ has been made by equilibration of heart muscle slices in a medium containing $\left(\mathrm{P}^{*} \mathrm{O}_{4}\right)$. The rate of penetration was $1.7 \mu \mathrm{gP} / \mathrm{gm}$ tissue $/ \mathrm{min}$. at $37^{\circ} \mathrm{C}$ and about $0.3 \mu \mathrm{gP} / \mathrm{gm}$ tissue $/ \mathrm{min}$. at $2^{\circ} \mathrm{C}$ (8) which was in agreement with data obtained earlier by Manery et al. (9). Equivalence between extracellular IP and that of the medium was reached in 10 to 30 minutes at either $2^{\circ}$ or $37^{\circ}$, but the specific activity of the intracellular IP increased with temperature as well as with time (8). The difference in $\mathrm{P}^{32}$ entering the cell at $2^{\circ}$ and at $37^{\circ}$ indicated that cell penetration by $\mathrm{PO}_{4}$ is not a simple matter of diffusion.

The specific activity of creatine phosphate (CP) was equal to that of intracellular inorganic phosphate while that of the labile phosphate of adenyl pyrophosphate (APP) was lower. The terminal phosphate of adenosine-triphosphate (ATP) had the same specific activity as IP and CP, while the remaining labile phosphorus of APP was lower by about one-half. These results were taken as evidence that intracellular IP and not total tissue IP was the source of supply of CP and APP (8). In frog gastrocnemius in vivo the specific activity of $\mathrm{CP}$ and of the labile $\mathrm{P}$ of the pyrophosphate fraction were found to be equal (7). Sacks and Altshuler (10) found a difference in the specific activity of IP and CP of both skeletal and heart muscle and concluded that extracellular and intracellular IP exchange through CP and APP as carriers (10). The interpretation has been criticized since their data were rather variable, since they assumed a fixed extracellular space and since they also assumed equilibrium in both concentration and radioactivity of plasma and extracellular IP (8). Bollman and Flock (11) found that in both resting and exercised limbs of the rat, the $P^{32}$ uptake was the same for both CP and APP and there was no increase in specific activity in the recovery period. These results would be expected if the fractions were in equilibrium with only intracellular IP during the experimental period. Furchgott and Shorr (8) calculated that there is almost complete turnover of labile organic phosphorus in the cell once every two minutes.

The phosphorus groups of ATP may be designated as follows :<smiles>[R]O[P+]([O-])(OC)OP(=O)(OC)OP(=O)(OC)OC</smiles>

In contrast to the rapid turnover in $\mathrm{P}^{2}$ and $\mathrm{P}^{3}$, the turnover rate for $\mathrm{P}^{1}$ was found to be slow (12-15). Kalckar et al. (15) made analyses after perfusing and they found that in skeletal muscle labile organic phosphate turned over at the rate of $25 \mu \mathrm{gP} /$ gm tissue/min. In ATP of rabbit muscle at $37^{\circ}$ the specific activities of $\mathrm{P}^{2}$ and $\mathrm{P}^{3}$ were the same, while in the frog muscle at low temperature the $\mathrm{P}^{2}$ was higher. In rabbit liver, pyrophosphate turnover was at the rate of $17 \mu \mathrm{g} / \mathrm{gm}$ tissue/min. 
Hexose monophosphate activity was either higher, lower or the same as the pyrophosphate of ATP, the variability being attributed to the extent of direct formation of phosphorylated sugar from glycogen and IP (15).

Kaplan and Greenberg (16) determined $\mathrm{P}^{32}$ uptake in a number of organic phosphorus compounds of rat liver. Instead of specific activity, they used the ratio of $\mathrm{P}^{32}$ in the fraction in question to the total acid soluble phosphorus as a measure of the $\mathrm{P}^{32}$ distribution in the various components of this fraction. The extracellular inorganic phosphorus was not separated or estimated so that calculations of absolute rates of turnover would be subject to considerable error $(8,15)$. Their data showed the uptake to be greatest in glucose-6phosphate and lowest in glycero-phosphate. The injection of glucose or insulin increased the level of $\mathrm{P}^{32}$ in ATP pyrophosphate but not in the hexosephosphate. The greatest increase was observed after administration of both insulin and glucose. They suggested that the ATP content of the liver was of primary importance in determining the shape of the glucose tolerance curve. (High fat and protein diets decreased $\mathrm{P}^{32}$ esterification [16].) Sacks reported an increase in the turnover of hexosephosphate as well as creatine phosphate and adenylpyrophosphate following the administration of insulin (17). In addition, $\mathrm{P}^{32}$ uptake by brain tissue in vitro is markedly increased on the addition of glucose (18).

In general the results seem to fit the concept of a rapid turnover of phosphorus in the intracellular phosphate ester pool with a much slower turnover of inorganic phosphorus from the extracellular phase to replace phosphorus "leaking" out of the cell.

\section{Nucleic acids and nucleoproteins}

The "residual protein" of tissues is that portion which remains after the extraction of the acid soluble and lipid fractions. This has sometimes been called the nucleoprotein fraction although strictly speaking nucleoprotein is only one portion although it may be by far the greatest in this moiety.

The apparent rate of renewal of desoxyribose nucleic acid in normal rabbit liver was found to be very slow $(19,20)$. However, the turnover in the residual nucleoprotein of normal liver nuclei was found to be quite rapid (21). Turnover rates for desoxyribonucleic acid (DNA) of several tissues have been calculated assuming equilibrium with intracellular IP where the latter was calculated from the $\mathrm{Na}^{24}$ space and the tissue IP so that calculations of absolute rates are subject to the errors previously mentioned $(8,15)$. The relative specific activities in order of decreasing activity were intestinal mucosa, sarcoma, spleen, liver, kidney. A regressing sarcoma gave the same DNA specific activity as one which was growing $(22,23)$. It was suggested that dividing or secreting cells may be more permeable to phosphate than others (1). Bone marrow DNA showed a very high specific activity and that for the thymus decreased with increasing age of the animal (24). The rate of $\mathrm{P}^{32}$ incorporation in DNA reported by Brues et al. (25) was much higher that that found by Hevesy and Ottesen (20) but was probably contaminated with RNA. Brachet (26) pointed out a parallelism between DNA turnover rate and the intensity of the nuclear alkaline phosphatase reaction.

The rate of $\mathrm{P}^{32}$ uptake by ribose nucleic acid (RNA) and its apparent turnover rate has been reported to be much higher than that for DNA $(25,27)$. In liver tissue the ratio of apparent turnover rates for RNA and DNA was found to be 30 , in spleen 3 and in mucosa 2 . This has been taken to indicate a high rate of actual turnover in the latter two tissues $(1,27)$. It may be significant that the relative RNA turnover in intestinal mucosa, spleen and liver parallels that for protein synthesis as determined with $\mathrm{N}^{15}$ labelled leucine (28).

Although many of the observations on $\mathrm{P}^{32}$ accumulation in DNA have been interpreted as indications of actual turnover, evidence had been advanced earlier that such an interpretation may not be justifiable. It has been shown that in tissue which is not mitotically active (normal liver), there is rapid movement of $\mathrm{P}^{82}$ containing constituents between the cytoplasm and the nucleoprotein of the mucleus so that the partition ratio remains practically constant from one hour to five days after $\mathrm{P}^{32}$ administration. In actively mitotic tissue (lymphoma, sarcoma, regenerating liver), however, there is a continuous rise in the partition ratio indicating movement into nuclear nucleoprotein (largely DNA) but little or none 
coming out. Since the tissues to which a rapid DNA turnover has been attributed are also those in which there is rapid cell division, it is apparent that accumulation in DNA and not turnover may be the more appropriate interpretation. It would seem advisable to reexamine data on the apparent dynamic equilibrium obtained with isotopes other than $\mathrm{P}^{32}$ to determine the extent to which the data may be explained by cell replacement as compared with molecular turnover.

\section{Nucleic acid turnover in relation to mitosis}

Using a simple new method for isolating nuclei, Marshak (21) compared the rate of $\mathrm{P}^{32}$ accumulation in mouse liver and mouse lymphoma and in normal and regenerating rat liver with the rates for the nuclei of the same tissues. Initial uptake by normal liver and by normal liver nuclei was greater than that by lymphomatous tissue, but eventually the retention was much greater in the tumor tissue. Although the ratio of $\mathrm{P}^{32}$ concentration in liver nuclei to that in the whole liver tissue remained constant over a period of from one hour to five days after $\mathrm{P}^{32}$ injection, in the lymphomas studied, this ratio showed a continual increase. Sarcoma 180 gave results similar to lymphoma, while regenerating liver, in contrast to normal liver, also showed increased accumulation in the nuclei. In the nuclei of normal liver 60-70 per cent of the $\mathrm{P}^{32}$ was in the residual nucleoprotein with the remainder in the acid soluble and lipid fractions. Approximately the same distribution was found at various times between one hour and seven days after $\mathrm{P}^{32}$ administration. In the lymphomas the residual nucleoprotein contained about 95 per cent of the nuclear $\mathrm{P}^{32}$. The data were taken as evidence that in the resting nucleus there is continual replacement of nuclear nucleic acid phosphorus at a rate greater than that required for complete replacement in one day. This is in striking contrast to the observations of Hahn and Hevesy on DNA extracted from tissue. Although there was obvious replacement in "resting" nuclei, with $\mathrm{P}^{32}$ in some form being rapidly built into the nucleic acid, and $\mathrm{P}^{32}$ containing components of nucleic acid also being rapidly removed to the cytoplasm, the situation in mitotic nuclei differed in that the $\mathrm{P}^{\mathbf{3 2}}$ was built into the nuclear nucleic acid with little or none being released to the cytoplasm. Calculations from the rate of $P^{32}$ accumulation in lymphoma nuclei showed that in 27 hours the nucleus had accumulated an amount equal to that initially present, i.e., an amount sufficient to form another nucleus. This was in approximate agreement with data on rate of growth of the tumor from which it was estimated that its weight was doubled in 24 hours (21).

Brues et al. (25) found that between three and eight days after $\mathrm{P}^{32}$ administration, the specific activities of nuclear residual protein and nuclear nucleic acid were each slightly higher than that of DNA extracted from the whole tissue. RNA had a much higher specific activity than DNA in normal liver but these were approximately the same in regenerating liver. The phospholipid of the nucleus was at all times in equilibrium with that of the cytoplasm, indicating that the low DNA uptake could not be due to exclusion of $\mathrm{P}^{32}$ from the nucleus as had been suggested by Hahn and Hevesy. The $\mathrm{P}^{32}$ uptake by DNA of a hepatoma was five times greater than in normal liver, but only half as much as in regenerating liver. A correlation between increase in $\mathrm{P}^{32}$ incorporation in DNA and mitosis was also reported by Kohman and Rusch (29) who found a greater $\mathrm{P}^{\mathbf{3 2}}$ uptake in nucleic acid of hepatoma as compared with normal liver. In the avian nucleated erythrocyte which does not undergo mitosis, the DNA specific activity does not decline until the erythrocytes are destroyed (30).

When $\mathrm{P}^{32}$-labelled chromatin, fat-free chromatin, or that portion of chromatin soluble in 1 $\mathrm{M} \mathrm{NaCl}$ were given intravenously to rats, the $\mathrm{P}^{32}$ was rapidly incorporated into the liver nuclei. Since the chromatin administered was particulate and could, therefore, be expected to accumulate in the liver, comparison was made of nuclear $\mathrm{P}^{32}$ uptake as per cent of the total liver $\mathrm{P}^{82}$ thus permitting comparison of nuclear $\mathrm{P}^{32}$ accumulation independent of the total tissue concentration. Comparison on this basis showed that nuclei accumulated over four times as much $\mathrm{P}^{32}$ when the source was fat-free chromatin as when it was inorganic phosphate, and twice as much as when it was phospholipid. This observation was correlated with the marked stimulation of mitosis produced when chromatin was injected into partially hepatectomized cats (31). $\mathrm{P}^{32}$-labelled DNA from Jensen sarcoma was injected as a solution into rats and two hours later a considerable amount of $\mathrm{P}^{\mathbf{3 2}}$ was found in the liver. The $\mathrm{P}^{32}$ concentration in the liver and kidney were about the same, while in the 
spleen it was much lower. Of the liver $\mathrm{P}^{32}$ about three-fourths was in the acid soluble fraction (32).

Ahlström et al. (32) and Hevesy (1) interpreted the findings of Marshak and Walker as another example of accumulation in the liver of foreign substances injected into the blood stream. However, this cannot be accepted as a correct interpretation since the basis of comparison used, as explained above, eliminates this source of error.

The rapid $\mathrm{P}^{32}$ incorporation into the residual nucleoprotein of resting nuclei found by Marshak when compared with the inactivity of DNA observed by other investigators and also the efficiency of chromatin as a $\mathrm{P}^{32}$ donor suggested the presence of a component of nuclear residual protein which was unusually active in $\mathrm{P}^{32}$ turnover.

Nuclei were isolated from animals that had received $\mathrm{P}^{32}$ three hours earlier and it was found that on incubation at $0^{\circ}-2^{\circ}$ very little or no $\mathrm{P}^{\mathrm{s2}}$, nucleotide or nucleic acid was removed but that at $37^{\circ}$ large amounts of polynucleotide of high specific activity were released. In saline the addition of ribonuclease (RNAse) doubled the $\mathrm{P}^{32}$ released while desoxyribonuclease (DNAse) gave only a 50 per cent increase. After digestion with ribonuclease, the addition of the DNAse released no more $\mathrm{P}^{32}$ than did native nuclear enzymes under the same conditions although very large amounts of unlabelled polynucleotides were liberated by the DNAse. The same results were obtained with normal and with regenerating liver. These observations therefore indicated that during the three hours the $\mathrm{P}^{\mathbf{3 2}}$ was in the animals, considerable amounts had been incorporated into nucleic acid but none into DNA. When the incubation was carried out in carbonate buffer at $\mathrm{pH}$ 7.0 and $\mathrm{pH} 7.5$, the $\mathrm{P}^{32}$ released was increased but the amount released in the presence of DNAse was less than when no enzyme was added and it was therefore suggested that this enzyme might bind the $\mathrm{P}^{32}$ containing substrate although it did not split it. In the buffer all of the $\mathrm{P}^{\mathbf{3 2}}$ containing nucleic acid was removed by native enzymes and/or added ribonuclease, the $\mathrm{P}^{32}$ not so removed could be accounted for as phospholipid and acid soluble organic phosphorus. The specific activity of the $\mathrm{P}^{32}$ containing nuclear substrate was 13 times greater than that of the cytoplasmic RNA. It was concluded that the two are functionally different substances although the substrate material might be the same as that fraction which could be iso- lated from nuclei by methods used for obtaining RNA, since they both had about the same specific activity. Since the nuclear autodigestion products were polynucleotides, it could be concluded that the nuclear enzymes involved were not the same as ribonuclease. Solubility studies showed that the $\mathrm{P}^{32}$ containing substrate differed from desoxyribonucleoprotein. Since $\mathrm{P}^{\mathbf{3 2}}$ first appears in this nucleoprotein in mitotic cells and does not appear in DNA until some time later, this material was considered to be the precursor of DNA in such cells. Earlier experiments had shown that in resting cells (normal liver) there was rapid exchange between nuclear and cytoplasmic $\mathrm{P}^{32}$ and not unidirectional accumulation by nucleus and DNA as in the case of mitotic nuclei (21). Under these conditions therefore the higher specific activity of the nuclear substrate indicated that in the resting cell it was the precursor to cytoplasmic RNA (44).

\section{$X$-ray effect on nucleic acid turnover}

Marshak (21) showed that low doses (200 r) of $\mathrm{X}$-rays produced an increase in the relative amount of $\mathrm{P}^{32}$ accumulated by nuclei of a mouse lymphoma although the total tissue uptake remained unchanged. Since the total tissue $\mathrm{P}^{32}$ was not altered, the observations could not be attributed to changes in permeability. The increase in nuclear $\mathrm{P}^{32}$ concentration varied with the dose. Since this effect was not observed in normal liver, the phenomenon was considered to be somehow associated with mitosis.

Euler and Hevesy (33) subsequently studied the effect of X-rays on the Jensen rat sarcoma. They found no significant effect with doses of 77$450 \mathrm{r}$ on $\mathrm{P}^{32}$ concentration in total nucleic acid of the tumor. At doses of 450-7,000 r, the nucleic acid $\mathrm{P}^{32}$ as per cent of the liver IP and plasma IP was much reduced. The results could not be explained as effects on cell permeability since there was a parallel reduction in ratios of nucleic acid $\mathrm{P}^{32}$ to IP and to plasma $\mathrm{P}$. This conclusion is valid only if the intracellular IP and the total tissue IP are not very different. A number of subsequent experiments gave further information on the reduction of $\mathrm{P}^{32}$ incorporation in DNA of sarcoma and liver, kidney, spleen and intestinal mucosa $(22,34,35)$.

As in the case of the mouse lymphoma and liver (21) a correlation between the known inhibition 
of mitosis and the X-ray effect on nucleic acid was established. However, there were these important differences. The significant effects observed by the Scandinavian investigators were obtained only at doses between 450 to $2,000 \mathrm{r}$ and were all in the direction of decreasing $\mathrm{P}^{32}$ incorporation into DNA. On the other hand, the results with the lymphoma were obtained at doses between 200 and $260 \mathrm{r}$ and were in the direction of increased $\mathrm{P}^{32}$ incorporation in the nuclei. With the rat sarcoma there was also marked reduction in the total $\mathrm{P}^{32}$ of liver, sarcoma, and plasma as well as of tumor IP following irradiation while in the mouse experiments there was no change in total $\mathrm{P}^{32}$ of the lymphoma. Experiments were performed on rats each bearing two tumors one of which was irradiated and the other carefully shielded and it was found that the non-irradiated tumor showed a decrease in DNA - $\mathrm{P}^{32}$ uptake almost as great as that of the irradiated tumor (22). The effect on DNA must, therefore, be an indirect one which is somehow produced by an initial systemic reaction. This explanation does not apply however to the results on lymphoma. Marshak has proposed a theory for the mode of action of X-ray which postulates an inhibition of conversion of the nuclear precursor to ribonucleic acid and correlates this inhibition with arrest of mitosis known to be produced (44).

\section{Bone}

$\mathrm{P}^{32}$ given as phosphate appears rapidly in bone $(36,37)$. Pecher showed that the relative concentration in bone as compared with soft tissue was lower than that observed with $\mathrm{Ca}^{45}$ and $\mathrm{Sr}^{89}$ which was anticipated because of the comparatively low Ca content of soft tissues (38). The concentration of $\mathrm{P}^{32}$ was greater in the spongy portion of bone and for this reason the specific activity of the epiphysis was at first higher than the diaphysis although, with time, this difference disappeared (39). The initial $\mathrm{P}^{32}$ deposition in bone was by ionic exchange with blood phosphate and the solid phase of bone; but this was altered later by the constant resorption and deposition which took place $(40,41)$. It has been proposed that mineral deposition occurs when a local excess of $\mathrm{PO}_{4}$ is produced by action of alkaline phosphatase on phosphate esters to the point where the solubility product of bone salt is exceeded (42). A quanti- tative method has been described for studying the healing of bone lesions by measuring $\mathrm{P}^{32}$ and $\mathrm{Sr}^{80}$ uptake in situ without disturbing the lesion and using the contralateral limb as a control. The ratio of strontium to phosphorus increased as the healing process progressed and it was suggested that this difference might be utilized in differentiation between the proliferating and calcifying stages (43). A decrease in the uptake of $\mathrm{P}^{32}, \mathrm{Ca}^{45}$ and $\mathrm{Sr}^{89}$ by bone in rickets and an increase in their uptake on administration of vitamin $\mathrm{D}$ has been demonstrated by several authors.

\section{BIBLIOGRAPHY}

1. Hevesy, G., in: Advances in Biological and Medical Physics, Edited by Lawrence, J. H., and Hamilton, J. G. Academic Press, New York, N. Y., 1948.

2. Hall, B. E., in: The Use of Isotopes in Biology and Medicine. University of Wisconsin Press, Madison, Wis., 1948.

3. Greenberg, D. M., in: The Use of Isotopes in Biology and Medicine. University of Wisconsin Press, Madison, Wis., 1948.

4. Hevesy, G., Radioactive Indicators; Their application in biochemistry, animal physiology, and pathology. Interscience Pub. Co., New York, N. Y., 1948.

5. Chaikoff, I. L., and Zilversmit, D. B., in: Advances in Biological and Medical Physics, Edited by Lawrence, J. H., and Hamilton, J. G. Academic Press, Inc., New York, N. Y., 1948.

6. Hevesy, G., and Euler, H., The permeability of the cell wall of the sarcoma to phosphate and the velocity of the neoformation of phosphorus-containing compounds in the sarcoma cells. Arkiv. Kemi, Mineral. Geol., 1942, A15, No. 15.

7. Hevesy, G., and Rebbe, O., Rate of penetration of phosphate into muscle cells. Acta physiol. Scandinav., 1940, 1, 171.

8. Furchgott, R. F., and Shorr, E., Phosphate exchange in resting cardiac muscle as indicated by radioactivity studies. J. Biol. Chem., 1943, 151, 65.

9. Manery, J. F., and Bale, W. F., The penetration of radioactive sodium and phosphorus into the extraand intracellular phases of tissues. Am. J. Physiol., 1941, 132, 215.

10. Sacks, J., and Altshuler, C. H., Radioactive phosphorus studied on striated and cardiac muscle metabolism. Am. J. Physiol., 1942, 137, 750.

11. Bollman, J., and Flock, E. V., Phosphocreatine and inorganic phosphate in working and resting muscles of rats, studied with radioactive phosphorus. J. Biol. Chem., 1943, 147, 155.

12. Korzybski, T., and Parnas, I. K., Observations sur les échanges des atomes du phosphore renfermés dans l'acide adénosinetriphosphorique, dans l'animal 
vivant, a l'aide du phosphore marqué par du radiophosphore "P. Bull. Soc. chim. biol., 1939, 21, 713.

13. Hevesy, G., Application of isotopes in biology, J. Chem. Soc., 1939, Part II, 1213.

14. Meyerhof, O., Ohlmeyer, P., Gentner, W., and Maier-Leibnitz, H., Studies on the intermediate reactions of glucolysis with the aid of radioactive phosphorus. Biochem. Ztschr., 1938, 298, 396.

15. Kalckar, H. M., Dehlinger, J., and Mehler, A., Rejuvination of phosphate in adenine nucleotides; rate of rejuvination of labile phosphate compounds in muscle and liver. J. Biol. Chem., 1944, 154, 275.

16. Kaplan, N. O., and Greenberg, D. M., Studies with radioactive phosphorus of the changes in the acidsoluble phosphates in the liver and coincident to alterations in carbohydrate metabolism, separation and nature of organic acid-soluble phosphates of liver. J. Biol. Chem., 1944, 156, 511.

17. Sacks, J., Effect of insulin on phosphorus turnover in muscle. Am. J. Physiol., 1945, 143, 157.

18. Schachner, H., Fries, B. A., and Chaikoff, I. L., Effect of hexoses and pentoses on formation in vitro of phospholipid by brain tissue as measured with radioactive phosphorus. J. Biol. Chem., 1942, 146, 95.

19. Hahn, L., and Hevesy, G., Turnover rate of nucleic acid. Nature, 1940, 145, 549.

20. Hevesy, G., and Ottesen, J., Rate of formation of nucleic acid in the organs of the rat. Acta physiol. Scandinav., 1943, 5, 237.

21. Marshak, A., $\mathbf{P}^{ \pm}$uptake by nuclei. J. Gen. Physiol., 1941, 25, 275.

22. Ahlström, L., Euler, H., and Hevesy, G., Indirect action of X-rays on Jensen sarcoma. Arkiv. Kemi, Mineral. Geol., 1945, 19A, No. 13.

23. Ahlström, L., Euler, H., and Hevesy, G., Turnover of nucleic acid in retrograde sarcomata. Arkiv. Kemi, Mineral. Geol., 1947, 24A, Nos. 12 and 24.

24. Andreasen, E., and Ottesen, J., Studies in the lymphocyte production. Investigations on the nucleic acid turnover in the lymphoid organs. Acta physiol. Scandinav., 1945, 10, 258.

25. Brues, A. M., Tracy, M. M., and Cohn, W. E., Nucleic acids of rat liver and hepatoma; their metabolic turnover in relation to growth. J. Biol. Chem., 1944, 155, 619.

26. Brachet, J., Nucleic acids in cell and embryo. Symp., Soc. Exper. Biol., 1947, 1, 207.

27. Hammarsten, E., and Hevesy, G., Rate of renewal of ribo- and desoxyribo-nucleic acids. Acta physiol. Scandinav., 1946, 11, 335.

28. Schoenheimer, R., Ratner, S., and Rittenberg, D., Studies in protein metabolism; metabolic activity of body proteins investigated with $1(-)$-leucine containing two isotopes. J. Biol. Chem., 1939, 130, 703.

29. Kohman, T. P., and Rusch, H. P., Relative metabolic activities of normal and tumorous liver nucleo- proteins indicated by radiophosphorus. Proc. Soc. Exper. Biol. \& Med., 1941, 46, 403.

30. Hevesy, G., and Ottesen, J., Life-cycle of the red corpuscles of the hen. Nature, 1945, 156, 534.

31a. Marshak, A., and Walker, A. C., Effect of liver fractions on mitosis in regenerating liver. Am. J. Physiol., 1945, 143, 226.

b. Marshak, A., and Walker, A. C., Transfer of $\mathbf{P}^{32}$ from intravenous chromatin to hepatic nuclei. Ibid., 235.

32. Ahlström, L., Euler, H., and Hevesy, G., Fate of nucleic acid introduced into the circulation. Arkiv. Kemi, Mineral. Geol., 1946, 22A, No. 7.

33. Euler, H., and Hevesy, G., Effect of $x$-rays on nucleic acid exchange in Jensen sarcoma tissue. Kgl. Danske Videnskab. Selskab., Biol. Medd., 1942, 17, No. 8, 3.

34. Ahlström, L., Euler, H., and Hevesy, G., Action of $x$-rays on nucleic acid metabolism in rat organs. Arkiv. Kemi, Mineral. Geol., 1944, 19A, No. 9.

35. Euler, H., and Hevesy, G., Action of $x$-rays on nucleic acid metabolism in Jensen sarcoma. Arkiv. Kemi, Mineral. Geol., 1944, 17A, No. 30.

36. Chievitz, O., and Hevesy, G., The metabolism of phosphorus in animals. Kgl. Danske Videnskab., Biol. Medd., 1937, 13, No. 9.

37. Manly, M. L., and Bale, W. F., Metabolism of inorganic phosphorus of rat bones and teeth as indicated by radioactive isotope. J. Biol. Chem., 1939, 129, 125.

38. Pecher, C., Biological investigations with radioactive calcium and strontium; preliminary on the use of radioactive strontium in the treatment of metastatic bone cancer. Univ. California Publ., Pharmacol., 1942, 2, 117.

39. Manly, R. S., Hodge, H. C., and Manly, M. D., Relation of phosphorus turnover of blood to mineral metabolism of calcified tissues as shown by radioactive phosphorus. J. Biol. Chem., 1940, 134, 293.

40. Johansson, E. G., Falkenheim, M., and Hodge, H. C., Adsorption of phosphates by enamel, dentin and bone; adsorption time studied by means of radioactive isotope. J. Biol. Chem., 1945, 159, 129.

41. Riley, R. F., McCleary, B., and Johnson, R. E., Denervation atrophy of bone and muscle; examination of effect of choline and some further observations on metabolism of phosphorylcholine and deposition of $\mathrm{P}^{\mathrm{sz}}$ in bone. Am. J. Physiol., 1945, 143, 677.

42. Greenberg, D. M., and Mohamed, S., Effect of lowered blood supply and of glucose 1-phosphate on healing of bone fractures. Proc. Soc. Exper. Biol. \& Med., 1944, 57, 203.

43. Marshak, A., and Byron, R. L., Jr., Method for studying healing of bone. J. Bone \& Joint Surgery, 1945, 27, 95.

44. Marshak, A., Evidence for a nuclear precursor of ribo- and desoxyribonucleic acid. J. Cell. \& Comp. Physiol., 1948, 32, 381. 